Філак Я.Ф., Філак Ф.Г.

\title{
Засоби фізичної терапії хворих на хронічний коліт 3 гіпомоторним синдромом та 3 вираженим остеохондрозом поперекового відділу хребта в умовах санаторію
}

\author{
ДВНЗ «Ужгородський національний університет», м. Ужгород, Україна \\ yaroslav.filak@uzhnu.edu.ua, filakfelix19@ukr.net
}

\section{Филак Я.Ф., Филак Ф.Г. \\ Средства физической терапии больных хроническим колитом с гипомоторным синдромом с выраженным остеохондрозом поясничного отдела позвоночника в условиях санатория}

ГВУЗ «Ужгородский национальный университет», г. Ужгород, Украина
Filak J.F., Filak F.G.

Means of physical therapy of patients with chronic colitis with hypomotor syndrome and severe osteochondrosis of the lumbar spine in the sanatorium

SU "Uzhhorod national university", Uzhhorod, Ukraine

\section{Вступ}

Хронічні запальні захворювання кишечника, у тому числі і хронічний коліт (ХК), за даними різних авторів, складають від $30 \%$ до $70 \%$ в структурі патології гастроентерологічного профілю і розглядаються сьогодні в аспекті ризику виникнення колоректального раку. В останній час у всьому світі відмічається прогресуюче зростання хвороб кишечника у зв'язку з урбанізацією життя, гіпокінезією, а також 3 такими негативними соціально обумовленими явищами, як неадекватне, незбалансоване харчування, алкоголізм, паління, наркоманія. Значний відсоток зростання захворюваань товстої кишки, які вражають щорічно до 800 тис. чоловік у всьому світі, а також збільшення смертності від них більш ніж в половині випадків, ставить цю патологію в ряд найважливіших медичних і соціальних проблем. 3 іншої сторони остеохондроз розглядають як одну із найбільш розповсюджених форм хронічного системного ураження сполучної, зокрема хрящової тканини, для якої характерно: тотальність і в той же час нерівномірність уражень окремих відділів хребта, особливо поперекового відділу, що негативно впливає на перебіг хвороб органів травлення. Проведені дослідження показали, що понад 80\% дорослого населення земної кулі відчуває біль у спині, має особистий (позитивний чи негативний) досвід лікування неврологічних проявів остеохондрозу хребта. Ці хвороби часто виникають у людей найбільш працездатного віку, викликають тривалу тимчасову непрацездатність, нерідко призводять до інвалідності [1,5].

Вивчивши та проаналізувавши ряд літературних джерел 3 даного питання, ми виявили той факт, що існує мало, досліджень, пов'язаних 3 упровадженням у комплексне відновне лікування хворих на хронічний коліт 3 гіпомоторним синдромом, які страждають на виражений остеохондроз хребта сучасних систем і методик фізичної терапії залежно від вихідного стану мотоної функції товстої кишки. У працях науковців доведено, що фізіотерапевтичні та кінезотерапевтичні чинники виконують важливу роль у відновлювальному лікуванні хворих на хронічний коліт. Разом з тим до теперішнього часу науково необгрунтовані реабілітаційні заходи, які б поєднували одночасний вплив на стан кишківника і хребта у обстежених хворих. Тому розробка нових ефективних методів фізичної терапії в в комплексному санаторному лікуванні хворих на хронічний коліт з остеохондрозом поперекового відділу хребта $\epsilon$ актуальним напрямом медичної науки $[2,4]$.

Мета роботи - науково обгрунтувати та удосконалити комплексну програму фізичної терапії для хворих на хронічний коліт 3 гіпомоторним синдромом 3 вираженим остеохондрозом поперекового в умовах санаторію.

\section{Об’скт і методи дослідження}

Об'єктом дослідження були 30 хворих на хронічний коліт із гіпомоторним синдромом у яких також діагностований виражений остеохондроз поперекового відділу хребта віком від 45 до 55 років, 3 них 18 чоловіків і 12 жінок. Контрольну групу становили 15 хворих на хронічний коліт з остеохондрозом хребта, які проходили стандартний реабілітаційний курс. При поступленні на відновне лікування в санаторій «Орлине гніздо» пацієнти були детально обстежені. Діагноз хронічний коліт базувався на даних клініко-лабораторних та інструментальних методів дослідження, остеохондроз поперекового відділу хребта на даних компютерної томографіi, які проводилися за місцем проживання. Тривалість санаторно-курортного лікування становила 
21 день. Для рішення основних задач нашого дослідження i контролю за функціональним станом хворих на хронічний коліт 3 гіпомоторним синдромом використовували такі методи дослідження на початку і в кінці курсу відновного лікування:

- аналіз літературних джерел;

- визначення показників фізичного розвитку;

- дослідження моторної функції кишечника;

- метод математичного статистики.

На початку дослідження було проведено опитування хворих з метою збору скарг, анамнезу життя і хвороби. Для вивчення стану моторної функції товстої кишки і оцінки ефективності реабілітаційних заходів проведена реєстрація міоелектричної активності сліпої та сигмовидної кишок методом електроколонографії за методикою А.М.Ногаллера, Т.К.Аверіної. Запис електроколонографії проводився зранку. Пацієнт повинен лежати нерухомо, оскільки найменший рух, навіть глибокий вдих можуть викликати спотворення справжньої картини. Обробка даних проводилася за Я.С.Цімерманом. При цьому визначалась середня частота і амплітуда зубців електроколонографії за допомогою лінійки-нормограми. Середне значення амплітуд у межах ділянки, що аналізується $(\mathrm{t}=10$ хв.). Розрахунки проводилися за формулою: $\mathrm{Acep}=\mathrm{An} / \mathrm{n}$, де $\mathrm{An}$ - сума всіх виміряних амплітуд; $\mathrm{n}$ - число вимірювань. Порівнювалась фонова міоелектрична активність товстої кишки та іï зміни на початку і в кінці курсу лікування. Результати оцінювали за показниками амплітуди та частоти тонічних коливань кишечника. При нормокінетичному типі електроколограми вольтаж зубців складав 0,12-0,14 мВ для сліпої кишки та 0,22-0,24 мВ - для сигмовидної.

Для з'ясування взаємовзаємодії м'язів спини та черевної порожнини застосовували тест: «витривалість сили м'язів черевного преса». Для цього 3 вихідного положення - лежачи на спині, руки уздовж тулуба, ноги прямі. Хворим пропонувалося підняти прямі ноги під кутом $45^{\circ}$ відносно опори, і втримувати в цьому положенні максимально можливий час $(\min -15 \mathrm{c} ; \max -35 \mathrm{c})$. Результат оцінювався: 30-35 с - відмінно; 25-30 с - добре; 20-25 с - задовільно; меньше - 20 с - незадовільно.

Статистична обробка матеріалів дослідження результати експерименту проводилася за t-критерієм Ст'юдента.

\section{Результати дослідження та їх обговорення}

За даними опитування практично всі хворі на хронічний коліт скаржилися на відчуття важкості в епігастрії, який відзначали 90,0\% хворих основної та $80,0 \%$ контрольної групи. Скарги на постійний ниючий біль в ділянці сигмовидної кишки, який поступово посилюється при ходьбі відзначали 76,6\% хворих основної групи та 73,3\% хворих контрольної групи. Здуття живота відзначали 80,0\% хворих основної та контрольної груп, бурчання по ходу кишечника відзначали 73,3\% хворих основної групи та $66,6 \%$ контрольної групи. Закрепи відзначали 100,0\% хворих обидвох груп. Дратівливість, емоційну нестійкість визначали 80,0\% хворих обидвох груп. При пальпації відзначали болючість по ходу товстої кишки особливо в ділянці сигмовидної кишки відзначали $73,3 \%$ хворих основної групи та 80,0\% хворих контрольної групи. Болі в поперековому відділі хребта відзначаали 100,0\% пацієнтів обидвох груп. Обмеження рухливості в попереку та напруження м'язів спини відзначали 93,3\% пацієнтів основної групи та $86,6 \%$ контрольної. Порушення загального стану у вигляді погіршення сну, загальної слабості відзначали $66,6 \%$ хворих основної групи та $60,0 \%$ хворих контрольної групи. Як видно клінічні показники у процентному відношені в основній і контрольній групі практично одинакові.

При нормокінетичному типі електроколограми вольтаж зубців складав $0,12-0,14$ мВ для сліпої кишки та 0,22-0,24 мВ - для сигмовидної. При дослідженні стану моторної функції кишечника натще у хворих хронічним колітом із гіпомоторним синдромом у 28 (93,3\%) обстежених відзначалось зниження міоелектричної активності сліпої та сигмовидної кишок. Найбільш характерні були низькоамплітудні тонічні і перистальтичні коливання сигмовидної кишки на фоні підвищення частоти ऑii тонічних скорочень, що спостерігалось у 27 (90,0\%) обстежених основної групи та у $13(86,6 \%)$ обстежениз контрольної групи. Це гіпотонічний-тахіритмічний тип моторики $(0,19 \pm 0,02 \mathrm{MB})$. Нормотонічний-тахіритмічний тип моторики сигмо видної кишки виявляли у 3 (10,0\%) основної групи та у 2 (13,3\%) хворих контрольної групи. Міоелектрична активність сліпої кишки у пацієнтів обох груп також знижена. Характерними $є$ низькоамплітудні тонічні і перистальтичні коливання вольтажу (мВ) сліпої кишки на фоні зниження частоти тонічних скорочень у всіх пацієнтів 30 (100,0\%) основної і 15 (100,0\%) контрольної груп $(0,09 \pm 0,01 \mathrm{MB})$.

Витривалість м'язів черевного преса для хворих

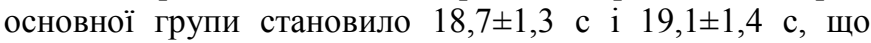
оцінювався як результат незадовільний.

Таким чином, у хворих, на хронічний коліт 3 гіпомоторним синдромом крім клінічних появів відзначаються: знижений тонус мязів черевного пресу, знижена моторна функція товстої кишки, розлади моторноевакуаторної функції кишечника, закрепи, ниючий біль та обмеження амплітуди рухів в поперековому відділі хребта. Найбільш характерні були низькоамплітудні тонічні i перистальтичні коливання сигмовидної кишки на фоні підвищення частоти іiі тонічних скорочень, що спостерігалось у обстежених обидвох груп, а також низькоамплітудні тонічні і перистальтичні коливання сліпої кишки на фоні зниження частоти тонічних скорочень у всіх пацієнтів 100,0\% основної і 100,0\% контрольної груп. Крім цього такі хворі відзначались підвищеною емоційною нестійкістю, зниженим настроєм, почуттям невдоволення собою у зв'язку зі станом свого здоров'я, зниженням працездатності.

В комплекс програми фізичної терапії входило: РГГ, лікувальна гімнастика, лікувальний класичний i сегментарно-рефлекторний масаж, внутрішній прийом мінеральної води «Поляна Квасова», вуглекислі мінеральні ванни, ампліпульстерапія на ділянку сигмовидної кишки, 
озокерит на поперек, внутрішній прийом мінеральної води Поляна Квасова. Мінеральну воду Поляна Квасова призначали температури $18^{\circ} \mathrm{C}$ за 20 хв. до прийому їжі натще в дозі 200 мл три рази в день. Спеціально підібрані засоби і форми ЛГ в комплексному відновному лікуванні сприяли загальному зміцненню м'язової системи та підвищення тонусу життєдіяльності організму хворого: розвитку i поліпшенню внутрішнього i особливо діафрагмального дихання; нормалізаціі секреторної, моторної, всмоктувальної функцій травного каналу; зміцненню м'язів спини і особливо м'язів черевного преса і тазового дна, зменшення болю в попереку та підвищення амплітуди рухів, а також регуляціі внутрішньочеревного тиску, почергове підвищення і пониження якого забезпечує профілактіку запорів, застійних явищ і спаєчних процесів. Вправи рекомендували виконувати 3 різних вихідних положень із підвищенням навантаження, силовими елементами. Проте слід дотримувати принцип поступового збільшення навантаження, диференційованого підходу до вибору гімнастичних вправ, враховувати реакції хворого на вправи. Тривалість занять лікувальною гімнастикою складає 30-35 хв.
Після проведення курсу реабілітаційних заходів відчуття важкості в епігастрії відзначали 13,3\% пацієнтів. Здуття живота після реабілітації також виявляли у 16,7\% пацієнтів, бурчання по ходу кишечника зменшилось у $50,0 \%$ хворих. Закрепи після реабілітації відзначали лише $20,0 \%$ хворих основної групи. Зникли явища дискомфорту, швидка втомлюваність, загальна слабкість, поганий сон. Болі в попереку, обмеження рухливості відзначали відповідно 13,3\% і 6,7\%.

У хворих контрольної групи для порівняння у комплекс лікувальної гімнастики входили загальнозміцнюючі вправи для всіх м'язових груп, для м'язів черевного пресу з невеликим обтяженням в поєднанні 3 дихальними вправами також відзначається позитивна динаміка клінічних показників, однак ці результати нижчі ніж в основній групі.

У ході контрольного тестування пацієнти виконували тест: утримання прямих ніг під кутом $45^{\circ}$ 3 в.П. - лежачи на спині, руки вздовж тулуба можливу кількість часу.

Результати дослідження витривалості м'язів черевного преса наведені в таблиці 2.

\section{Таблиця 1. Основні клінічні показники хворих на хронічний коліт з гіпомоторним синдромом}

\begin{tabular}{|l|l|c|c|}
\hline $\begin{array}{c}\text { № } \\
\text { п/п }\end{array}$ & \multicolumn{1}{|c|}{ Клінічні показники } & \multicolumn{2}{|c|}{$\begin{array}{c}\text { Основна група, абс. (\%) } \\
\text { Після реабілітації }\end{array}$} \\
\hline 1 & Відчуття важкості в епігастрії & $27(90,0)$ & $4(13,3)$ \\
\hline 2 & Постійний ниючий біль в ділянці сигмовидної кишки & $23(76,6)$ & $2(6,7)$ \\
\hline 3 & Здуття живота & $24(80,0)$ & $7(16,7)$ \\
\hline 4 & Бурчання по ходу кишечника & $22(73,3)$ & $7(23,3)$ \\
\hline 5 & Закрепи & $30(100,0)$ & $6(20,0)$ \\
\hline 6 & Дратівливість, емоційну нестійкість & $24(80,0)$ & $9(30,0)$ \\
\hline 7 & Болючість в ділянці кишечника & $22(73,3)$ & $7(23,3)$ \\
\hline 8 & Болі в попереку & $30(100,0)$ & $4(13,3)$ \\
\hline 9 & Обмеження рухливості в попереку & $28(93,3)$ & $2(6,7)$ \\
\hline
\end{tabular}

Таблиця 2. Показники витривалості м'язів черевного преса в процесі ФР у хворих на хронічний коліт

\begin{tabular}{|l|c|c|c|}
\hline \multicolumn{1}{|c|}{ Група } & \multicolumn{2}{c|}{ Час утримання пози, с } & п \\
\hline Основна $(\mathrm{n}=30)$ & до курсу реабілітації курсу реабілітації & $<0,05$ \\
\hline Контрольна $(\mathrm{n}=15)$ & $18,7 \pm 1,3$ & $29,5 \pm 1,4$ & $>0,05$ \\
\hline
\end{tabular}

Як видно з таблиць, до початку курсу реабілітації час утримання заданої пози в обох групах хворих був приблизно однаковим і становив в контрольній групі $19,1 \pm 1,5$ с, а в основній $18,7 \pm 1,3$ с. Після завершення курсу фізичної терапії у хворих основної групи цей час дорівнював 29,5 $\pm 1,4$ с, який оцінюється як «добре», а в контрольній групі - 23,8 $\pm 1,9$ с, який оцінюється як «задовільно». Покращення результатів в основній групі становило 10,8 с, тоді як у контрольній 4,7 с, що вказує на ефективність запропонованої комплексної програми.

У хворих на хронічний коліт після проведених реабілітаційних заходів у пацієнтів основної групи вірогідно підвищилися показники частоти тонічних хвиль сліпої ( $\mathrm{P}<0,05$, з 0,51 $\pm 0,02$ до $0,65 \pm 0,03 \mathrm{mB}(\mathrm{P}<0,05)$, сигмовидної $0,55 \pm 0,01$ до $0,69 \pm 0,05 \mathrm{mB}(\mathrm{P}<0,05)$ кишок. Відзначається також достовірне підвищення показників амплітуди тонічних хвиль сліпої (з $0,16 \pm 0,01$ до $0,20 \pm$ $0,006 \mathrm{мB}$ ), сигмовидної (з $0,18 \pm 0,009$ до $0,24 \pm 0,02 \mathrm{mB}$ ) $(\mathrm{P}<0,05)$ кишок. У контрольній групі відзначається тенденція до нормалізації показників частоти та амплітуди тонічних хвиль товстої кишки.

Таким чином, після проведеного комплексу реабілітаційних заходів у хворих на хронічний коліт 3 гіпомоторним синдромом відзначається позитивна 
динамікав клінічних показників, порушення функцій інших органів травної системи, нормалізація моторної функції товстого кишечника, зменшення болю в попереку та підвищення амплітуди рухів. Після проведеного курсу реабілітаційних заходів позитивна динаміка відзначена в обидвох групах, однак кращі результати виявлені у пацієнтів основної групи.

\section{Висновки}

1. Підсумовуючи результати спостережень за пацієнтами хворих на хронічний коліт 3 гіпомоторним синдромом в поєднанні 3 остеохондрозом поперекового відділу хребта встановлено, що крім клінічних проявів відзначаються: знижений тонус м'язів черевного пресу, недостатня моторна функція товстої кишки, розлади моторно-евакуаторної функції кишечника, підвищенна напруженість попорекових м'язів, обмеження рухливості, а це ускладнює перебіг і відновне лікування хвороби.

2. Провівши порівняльне обстеження, можемо вважати, що на фоні санаторно-курортної терапії внутрішній прийом мінеральної води, лікувальна гімнастика та сегментарно-рефлекторний масаж $є$ одним iз провідних методів відновного лікування для хворих даної патології.

3. Проведені дослідження показників фізичного розвитку після комплексу реабілітаційних заходів свідчать, що результати тесту на витривалість м'язів черевного пресу збільшились у пацієнтів основної групи 3 $18,7 \pm 1,3$ с до 29,5 $\pm 1,4$ с, який оцінюється як «добре», у

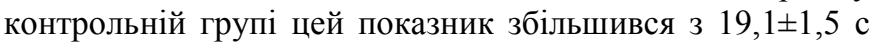
до $23,8 \pm 1,9$ с, який оцінюється як «задовільно».

\section{Література}

1. Бабак О.Я., Харченко Н.В. Рациональная диагностика и фармакотерапия заболеваний органов пищеварения. - К. : ООО «ОИРА «Здоров’я України», 2005. - 320 с.

2. Батманчхелидж Ф. Как лечить боли в спине и ревматические боли в суставах / Пер. с англ. Т.В. Лихач, О.Г. Белошеев. - Минск: Изд-во «Попурри», 2006. - 144 с.

3. Вдовиченко В.І., Бичков М.А., Денисюк Я.С. Функціональні захворювання органів травлення у світлі Римських III критеріїв. - Львів, 2010. - 105 с.

4. Дорофеев А.Э., Звягинцева Т.Д., Харченко Н.В. Заболевания кишечника. - Горлівка: Ліхтар, 2010. - 532 с.

5. Скляров О.Я., Косий О.Я., Скляров С.Я. Запальні захворювання товстої кишки. Основи гастроентерології. 2011. $-289 \mathrm{c}$.

6. Степанов Е. Г. Основы курортологии и санаторно-курортное лечение: учеб. пособие. - Харьков: «Кроссроуд», 2007. $-584 \mathrm{c}$.

\section{References}

1. Babak O.Ya., Kharchenko N.V. Ratsyonalnaia dyahnostyka y farmakoterapyia zabolevanyi orhanov pyshchevarenyia. K.: OOO «OYRA «Zdorovia Ukrainy»; 2005. 320 s. [in Russian].

2. Batmanchkhelydzh F. Kak lechyt boly v spyne y revmatycheskye boly v sustavakh / Per. s anhl. T.V. Lykhach, O.H. Belosheev. Mynsk: Yzd-vo «Popurry»; 2006. 144 s. [in Russian].

3. Vdovychenko V.I., Bychkov M.A., Denysiuk Ya.S. Funktsionalni zakhvoriuvannia orhaniv travlennia u svitli Rymskykh III kryteriiv. Lviv; 2010. 105 s. [in Ukrainian].

4. Dorofeev A.Э,. Zviahyntseva T.D. Kharchenko N.V. Zabolevanyia kyshechnyka. Horlivka: Likhtar; 2010. 532 s. [in Russian].

5. Skliarov O.Ya., Kosyi O.Ya., Skliarov Ye.Ya. Zapalni zakhvoriuvannia tovstoi kyshky. Osnovy hastroenterolohii; 2011. 289 s. [in Ukrainian].

6. Stepanov E.H. Osnovy kurortolohyy y sanatorno-kurortnoe lechenye: ucheb. Posobye. Kharkov: «Krossroud»; 2007. 584 s. [in Russian].

Дата надходження рукопису до редакції: 18.12 .2019 р.

Мета роботи: науково обгрунтувати та удосконалити комплексну програму фізичної терапії для хворих на хронічний коліт з гіпомоторним синдромом з вираженим остеохондрозом поперекового в умовах санаторію.

Матеріали та методи. Дослідження проведені у 30 хворих на хронічний коліт з гіпомоторним синдромом віком у яких також діагностований виражений остеохондроз поперекового відділу хребта від 45 до 55 років, з них 12 чоловіків і 18 жінок. Використовували такі методи дослідження: визначення показників фізичного розвитку, дослідження моторної функції кишківника.

Результати. Після проведеного комплексу реабілітаційних заходів у хворих на хронічний коліт з гіпомоторним синдромом відзначається позитивна динамікав клінічних показників, нормалізація моторної функції товстого 
кишечника, покращились показники витривалості м'язів черевного пресу, зменшення болю в попереку та підвищення амплітуди рухів.

Висновки. Доведена ефективність використання розроблених нами комплексу реабілітаційних заходів, які спрямовані на покращання клінічних, показників нормалізацію моторно-евакуаторної, секреторної функцій шлунковокишкового тракту, нервово-психічної сфери.

Ключові слова: фізична терапія, лікувальна гімнастика, остеохондроз хребта, хронічний коліт.

Цель работы: научно обосновать и усовершенствовать комплексную программу физической терапии для больных хроническим колитом с гипомоторным синдромом с выраженным остеохондрозом поясничного в условиях санатория.

Материалы и методы. Исследования проведены у 30 больных хроническим колитом с гипомоторным синдромом возрастом в которых также диагностирован выраженный остеохондроз поясничного отдела позвоночника от 45 до 55 лет, из них 12 мужчин и 18 женщин. Использовали такие методы исследования: определение показателей физического развития, исследования моторной функции кишечника.

Результаты. После проведенного комплекса реабилитационных мероприятий у больных хроническим колитом с гипомоторным синдромом отмечается положительная динамикав клинических показателей, нормализация моторной функции толстого кишечника, улучшились показатели выносливости мышц брюшного пресса, уменьшение боли в пояснице и повышение амплитуды движений.

Выводы. Доказана эффективность использования разработанных нами комплекса реабилитационных мероприятий, направленных на улучшение клинических, показателей нормализацию моторно-эвакуаторной, секреторной функций желудочно-кишечного тракта, нервно-психической сферы.

Ключевые слова: физическая терапия, лечебная гимнастика, остеохондроз позвоночника, хронический колит.

Aim of the study: scientific substantiation and improvement of comprehensive program of physical therapy for patients with chronic colitis with hypomotor syndrome and severe osteochondrosis of the lumbar spine in the sanatorium.

Materials and methods. Studies were performed with 30 patients with chronic colitis with hypomotor syndrome and diagnosed severe osteochondrosis of the lumbar spine aged between 45 and 55 years, including 12 men and 18 women. The following research methods were used: determination of physical development indicators, study of intestinal motor function.

Results. According to the survey in patients with chronic colitis with hypomotor syndrome, in addition to clinical manifestations are present: decreased tone of the abdominal muscles, disorders of motor-evacuation function of the intestine, constipation. The most characteristic were the low-amplitude tonic and peristaltic oscillations of the sigmoid colon against the background of increasing the frequency of its tonic contractions, as well as the low-amplitude tonic and peristaltic oscillations of the caecum. After the completion of the course of physical rehabilitation, beside with the improvement of the clinical picture, endurance of the abdominal muscles and bowel motility is improved.

Conclusions. The efficiency of uses complex rehabilitation measures, developed by us, aimed at improving the clinical and laboratory indicators, normalization of the motor-evacuation, secretory functions of the gastrointestinal tract, the neuropsychic sphere is proved.

Key words: physical therapy, therapeutic gymnastics, spinal osteochondrosis, chronic colitis.

Конфлікт інтересів: відсутній.

Conflicts of interest: authors have no conflicts of interest to declare.

\section{Відомості про авторів}

Філак Ярослав Феліксович - кандидат наук з фізичного виховання та спорту, доцент, завідувач кафедри фізичної реабілітації ДВНЗ «Ужгородський національний університет»; 88001, м. Ужгород, вул. І. Франка 1. +380 (50) 654-10-34, yaroslav.filak@uzhnu.edu.ua.

Філак Фелікс Георгійович - кандидат медичних наук, доцент, доцент кафедри основ медицини ДВНЗ «Ужгородський національний університет»; 88001, м. Ужгород, вул. І. Франка 1.

+380 (97) 992-13-00, filakfelix19@ukr.net. 